\title{
Metal-rich soils increase tropical tree stoichiometric distinctiveness
}

\author{
Liam A. Trethowan (D) B Benjamin Blonder • \\ Endang Kintamani • Deden Girmansyah • \\ Timothy M. A. Utteridge • Francis Q. Brearley
}

Received: 7 October 2020 / Revised: 6 January 2021 / Accepted: 11 January 2021 / Published online: 31 January 2021

(C) The Author(s) 2021

\begin{abstract}
Background and aims Ultramafic soils have high metal concentrations, offering a key opportunity to understand if such metals are strong predictors of leaf stoichiometry. This is particularly relevant for tropical forests where large knowledge gaps exist.

Methods On the tropical island of Sulawesi, Indonesia, we sampled forests on sand, limestone, mafic and ultramafic soils that present a range of soil metal concentrations. We asked how variation in 12 soil elements (metals and macronutrients) influenced leaf
\end{abstract}

Responsible Editor: Wen-Hao Zhang.

L. A. Trethowan - T. M. A. Utteridge

Herbarium Kew, London, UK

L. A. Trethowan $(\bowtie) \cdot$ F. Q. Brearley

Manchester Metropolitan University, Manchester, UK

e-mail: 1.trethowan@kew.org

B. Blonder

University of California at Berkeley, Berkeley, CA, USA

B. Blonder

Arizona State University, Tempe, AZ, USA

B. Blonder

University of Oxford, Oxford, UK

E. Kintamani · D. Girmansyah

Herbarium Bogoriense, Cibinong, Indonesia stoichiometry and whether stoichiometric distinctiveness (the average difference between a species and all others in a multivariate space, the axes of which are the concentrations of each leaf element) is influenced by increasing soil metal concentrations.

Results Positive correlations between corresponding elements in soils and leaves were only found for $\mathrm{Ca}$ and $\mathrm{P}$. Noticeably, soil $\mathrm{Cr}$ had a negative effect upon leaf $\mathrm{P}$. Whilst most species had low stoichiometric distinctiveness, some species had greater distinctiveness on stressful metal-rich ultramafic soils, generally caused by the accumulation of $\mathrm{Al}, \mathrm{Co}, \mathrm{Cr}$ or $\mathrm{Ni}$.

Conclusions Our observation of increased stoichiometric distinctiveness in tropical forests on ultramafic soils indicates greater niche differentiation, and contrasts with the assumption that stressful environments remove species with extreme phenotypes.

Keywords Ecological stoichiometry · Functional distinctiveness · Indonesia $\cdot$ Limestone $\cdot$ Mafic $\cdot$ Sand · Serpentine $\cdot$ Sulawesi

\section{Introduction}

Relationships between the majority of elements found in soils and plant tissues are poorly understood (Kaspari and Powers 2016). Species' stoichiometry (the balance of elements in an organism) may match the environment, or species could preferentially take up key elements needed for plant function (Turner et al. 2018). Equally, if uptake of an element has negative 
consequences, they can actively be excluded by species (Kazakou et al. 2008). For species that tolerate and survive on contrasting soil types, the relationships between tissue stoichiometry and the mosaic of elements available in the environment is unlikely to be simple (Kaspari and Powers 2016). Tissue elements may be primarily influenced by that same element in the soil. However, elemental concentrations are often tied to a different element that plays an indirect role in uptake (Yuan et al. 2011; Liu et al. 2017). For instance, in Arabidopsis, nitrate uptake is reliant upon calciumsignalling pathways (Liu et al. 2017). Alternatively, elements may have a negative effect upon one another because of competition for identical membrane transporters. For instance, $\mathrm{Fe}$ and Co use the same membrane transporter, and when the latter element is available in the environment it limits the former's uptake (Lange et al. 2017). Whilst relationships between plants and soils for macronutrients are well studied, many essential elements have received little attention (Kerkhoff et al. 2006; Elser et al. 2010; Kaspari and Powers 2016). Elements such as $\mathrm{Al}, \mathrm{Ca}$ and $\mathrm{Mg}$ are only occasionally examined (Tripler et al. 2006; Metali et al. 2015; Zemunik et al. 2018), whereas other metallic elements, e.g. $\mathrm{Cu}, \mathrm{Ni}$ and $\mathrm{Zn}$, are even less well understood (van der Ent et al. 2018b).

In most ecosystems, soil stoichiometry is a good predictor of plant stoichiometry (Thompson et al. 1997; Tuah et al. 2003; Metali et al. 2015). In tropical tree communities however, there is little clarity about metal element uptake and its influence on co-uptake of macronutrients (Zemunik et al. 2018). Understanding effects of metallic elements is important because they can be toxic for plants. $\mathrm{Cu}, \mathrm{Ni}, \mathrm{Zn}$ etc. can damage the machinery behind plant processes responsible for growth (photosynthesis, respiration) and therefore can indirectly affect competitive interactions between individuals/species (Küpper and Andresen 2016; Mohiley et al. 2020). Without a greater understanding of metals in plants we cannot be sure how stoichiometry influences the functioning of tropical ecosystems and the huge number of species they support (Cleveland et al. 2011).

Plants with different traits build their tissues and organs with different concentrations of elements (Ågren 2008). For example, plant species with short lived, delicate leaves have greater foliar $\mathrm{P}$ whilst those with long lived, tough leaves can have low P concentrations (Wright et al. 2004; Sardans and Peñuelas
2013). Likewise, below ground, fine root $\mathrm{N}$ concentrations are positively correlated with respiration but negatively with traits associated with toughness (Roumet et al. 2016). Therefore, trait shifts caused by the environment should lead to parallel shifts in stoichiometry (Meunier et al. 2017).

For plant function to change, the suite of elements in plants must also change. This suite can be represented by a multivariate space, the axes of which are based upon concentrations of each element. A species' position within this space can therefore be thought of as a measurement of plant function based upon stoichiometry (González et al. 2017; Ågren and Weih 2020). The differences between species within this space represents functional differences between them (Violle et al. 2017). These differences can be quantified using a measure known as 'functional distinctiveness' - the average distance between a species and all others in a multivariate space based upon functional traits (Grenié et al. 2017). Functional distinctiveness is important because it is linked to competition (MacArthur and Levins 1967), niche differentiation and abundance (Kraft et al. 2015; Umaña et al. 2017b). The ties between plant stoichiometry and function suggest that stoichiometric functional distinctiveness, with trait axes corresponding to tissue element concentrations, should be equally useful for predicting competition and niche differentiation within communities.

Stoichiometry is constrained by minimum element concentrations needed for cellular function and by maximum concentrations, beyond which a toxicity threshold is crossed (Meunier et al. 2014). Within these constraints, distinctiveness may vary dependent upon fitness differences associated with contrasting stoichiometry. If there is one point of optimum fitness we would expect a single mode in the distinctiveness distribution (Parker and Maynard Smith 1990). Conversely, there may be multiple optima due to trade-offs between different elements (Marks and Lechowicz 2006; D'Andrea et al. 2020; Worthy et al. 2020). For instance, one optimal strategy may require an element that shares a membrane transporter with another. This second element would be outcompeted at transporters if the first is found at high concentrations (Andresen et al. 2018). The second element at higher concentrations may offer an equal fitness benefit but would likewise outcompete the first element for transport/uptake. The two approaches, of equal fitness, would result in very different stoichiometry. This could lead to multiple fitness optima 
associated with multiple modes in the stoichiometric distinctiveness distribution (Laughlin et al. 2015). The environment should also be influential: for instance, a more variable environment may support a greater range of trait strategies (Kraft et al. 2008; Stark et al. 2017) as a result of there being more fitness optima (Levin and Muller-Landau 2000; Marks and Lechowicz 2006). If this is the case, we would expect an effect of soil element concentrations upon stoichiometric distinctiveness.

For some species, the hyperaccumulation of tissue metal beyond the thresholds of most other species can be a viable strategy to deal with high metal concentrations in soils (van der Ent et al. 2013a; Andresen et al. 2018). Most species exclude potentially detrimental metals. Some species do accumulate metals however metal chelators aid transport to the relatively metabolically inactive vacuole or cell wall for storage (Peng et al. 2020). Exogenous storage in high concentration patches on leaves has also been observed (van der Ent et al. 2018a). To examine the accumulation of metals in tropical tree species we sampled the little studied, speciesrich forests over ultramafic soils (van der Ent et al. 2018b; Lopez et al. 2019). Ultramafic soils derive from the weathering of mantle derived geology rich in metals e.g. Ni, Co and Cr (Moores 2011). The stoichiometry of the resulting soils reflects this weathering (high $\mathrm{Ni}, \mathrm{Co}$, Cr etc.), as can their plant communities - which feature the vast majority of metal hyperaccumulators (van der Ent et al. 2013a). Here we quantify multi-element soiltree stoichiometry across tropical ultramafic and nonultramafic sites.

This study focuses on Sulawesi, an island in central Indonesia, part of the Wallacea biodiversity hotspot that features the tropics' largest outcrop of ultramafic soils (van der Ent et al. 2013b; Galey et al. 2017). Forest plots were established on sand, limestone, mafic and ultramafic soils (Trethowan et al. 2020). We examine the relationships between $\mathrm{Al}, \mathrm{Ca}, \mathrm{Co}, \mathrm{Cr}, \mathrm{Cu}, \mathrm{Fe}, \mathrm{K}, \mathrm{Mg}$, $\mathrm{Mn}, \mathrm{Ni}, \mathrm{P}$ and $\mathrm{Zn}$ in soils vs. leaf tissue, and test how variability of these elements in soil affects tree species stoichiometry and stoichiometric distinctiveness.

\section{Materials and methods}

Sample collection

Ten $50 \times 50 \mathrm{~m}$ permanent primary forest plots were established across Sulawesi (Trethowan et al. 2020).
Study locations were centred around the tropics' largest mafic/ultramafic complex (van der Ent et al. 2013b). Two plots were located on ultramafic soils, at the complex's centre, in Morowali Nature Reserve. We established four plots at the complex's eastern periphery, in protected forests of the Bualemo peninsula. This consisted of two plots on mafic (basalt) soils, a single plot on a limestone hill and another in a limestone valley. Four plots were located at the south-eastern periphery, in protected forest of Wawonii Island. These consisted of two plots on ultramafic soils and two on sand.

We sampled all trees $\geq 10 \mathrm{~cm}$ diameter at breast height $(1.3 \mathrm{~m})$. Herbarium specimens were collected for species identification (Utteridge and Bramley 2015; Baker et al. 2017). Samples for tissue elemental analysis consisted of mature, shade leaves from all species in each plot. Shade leaves were collected because shade is the condition that most leaves experience (Keenan and Niinemets 2016) and, on a practical basis, were more accessible to tree climbers - this does however mean we did not examine sun-exposed leaves which may show different responses. One or two leaves were collected from a single branch and heat dried in the field; to avoid soot deposition, leaves were placed within envelopes during drying. Soil samples were taken from the upper $10 \mathrm{~cm}$ of topsoil at the centre of all $10 \times 10 \mathrm{~m}$ subplots; all samples from each plot were then pooled for further analysis giving us a total of ten soil samples for analysis. We acknowledge these pooled samples will have led to us missing fine scale edaphic influences on foliar stoichiometry. All plots had 'upland' soils so did not experience waterlogging. The upper $10 \mathrm{~cm}$ of topsoil is generally representative of the nutrients tropical trees are exposed to because this is where up to half of the total fine root mass is found, with an exponential decline in mass with soil depth (Brearley 2013; Lalnunzira et al. 2019).

\section{Leaf tissue stoichiometry}

A total of 723 leaf samples were collected from 283 species. The number of samples per plot ranged from 47 to 105 . Species richness ranged from 38 to 53 across the plots. Generally, each species was sampled once in each plot it occurred within. When species were sampled more than once in each plot the mean element concentration of that species within the plot was used. A subsample of each of the leaves (c. $100 \mathrm{mg}$ ) was digested in $10 \mathrm{ml}$ of concentrated $\mathrm{HNO}_{3}$ using a CEM 
Mars Xpress microwave ( $1200 \mathrm{~W}$ with a 15 minute ramp and 20 minute hold time at $170{ }^{\circ} \mathrm{C}$ ) and made up to $100 \mathrm{ml}$ in ultrapure (18 $\mathrm{M} \Omega$ ) deionised water. $\mathrm{Al}, \mathrm{Ca}, \mathrm{Co}, \mathrm{Cr}, \mathrm{Cu}$, $\mathrm{Fe}, \mathrm{K}, \mathrm{Mg}, \mathrm{Mn}, \mathrm{Ni}, \mathrm{P}$ and $\mathrm{Zn}$ concentrations were quantified using a Thermo-Finnegan iCAP 6300 Duo inductively coupled plasma optical emission spectrometer.

For quality control, certified reference material (LGC 7162, Strawberry Leaves) was analysed alongside the samples. Reference sample measurements did not differ from certified values for any element (Wilcoxon $\mathrm{P}>0.05$ ). Additionally, 61 leaf samples were washed by sonicating for five minutes in deionised water to determine if there was any soil contamination. The sonicated samples did not differ from unwashed samples (Wilcoxon $\mathrm{P}>0.05$ ) indicating our samples were not contaminated; we therefore used unwashed samples for all analyses.

Soil stoichiometry data

Total soil Al, Ca, Co, Cr, Cu, Fe, K, Mg, Mn, Ni, P and $\mathrm{Zn}$ were quantified via digestion of $0.5 \mathrm{~g}$ of thoroughly ground and homogenised soil in $5 \mathrm{ml} \mathrm{HNO}$ and $1 \mathrm{ml}$ $\mathrm{HClO}_{4}$ at 100 to $200{ }^{\circ} \mathrm{C}$ by ramping over 7 hours. Samples were diluted to $25 \mathrm{ml}$ with deionised water and analysed on an Agilent Technologies 4100 microwave plasma atomic emission spectrometer $(\mathrm{Co}, \mathrm{Cr}$ and Ni) or an Agilent Technologies 200 Series atomic absorption spectrometer (all other elements).

Edaphic effect upon species leaf stoichiometry

We explored the relationships between soil and leaf elements using partial least squares regression (PLS) this approach identifies the effects of multiple predictor variables while accounting for covariation amongst them (Wehrens and Mevik 2007). We square roottransformed all soil and leaf element concentrations to reduce the influence of outlying values, then scaled ( $\mathrm{z}$ scores used) prior to PLS to ensure regression coefficient estimates were comparable between elements. In a single model, we tested for the effect of each soil element upon each leaf element, whilst accounting for covariation in soil elements.

Edaphic effect upon species stoichiometric distinctiveness

Our distinctiveness measure was the mean distance of a species to all others in a multivariate space, the axes of which were each scaled (z-score) leaf element concentration (Violle et al. 2017). We did not reduce leaf stoichiometry axes down to a set of PC axes because there was little covariation between elements (nine PC axes were required to explain $90 \%$ of the variation in the data).

To examine edaphic influence on leaf stoichiometry, we used phylogenetic generalised least square regression (PGLS) following Metali et al. (2012). We incorporated phylogenetic distance into the analysis because related species are not independent samples (Hurlbert 1984; Verboom et al. 2017; Ives 2018). The square-root of species stoichiometric distinctiveness was the response variable and soil principal component (PC) axes were the predictor variables.

Phylogenetic data were derived from a plant family resolved supertree provided by Gastauer et al. (2017), pruned to consist of the taxa identified across the plot series using Phylomatic (Webb and Donoghue 2005). The resolved phylogeny was then dated according to Magallón et al. (2015).

All analyses were performed in R version 3.4.1 ( $\mathrm{R}$ Core Team 2019). The phylogeny was dated with the Bladj algorithm in PhylocomR 0.3.2 (Ooms et al. 2018), PLS regression was performed with pls 2.7 (Wehrens and Mevik 2007), stoichiometric distinctiveness was quantified with funrar 1.3.1 (Grenié et al. 2017), and PGLS regression was performed with nlme 3.1 (Pinheiro et al. 2013).

\section{Results}

Edaphic effect upon species leaf stoichiometry

We found that the first two partial least squares axes explained $72 \%$ of the variability in the relationship between soil and leaf element concentrations. These two axes showed large positive effects (regression coefficient $>0.1$ ) of soil $\mathrm{Al}$ and $\mathrm{P}$ concentration upon leaf $\mathrm{Ca}, \mathrm{Cu}$, and $\mathrm{P}$ concentration, and soil $\mathrm{Ca}$ concentration upon leaf $\mathrm{Ca}$ and $\mathrm{P}$ concentration (Fig. 1a). We found large positive effects of soil $\mathrm{Cr}$ and $\mathrm{Fe}$ concentration upon leaf Ni concentration (Fig. 1a). Large negative effects (regression coefficients $<-0.1$ ) were found for soil $\mathrm{Cr}$ concentration upon concentration of leaf $\mathrm{P}$ (Fig. 1a). Generally, we did not find clear effects of soil elements upon the reciprocal element in leaves, except 
for Ca and P (Fig. 1b). All soil and leaf element pairwise relationships can be found in Fig. S1.

Edaphic effect upon species stoichiometric distinctiveness

Five $\mathrm{PC}$ axes explained $>90 \%$ variation in the soil data. The first axis was responsible for a gradient of $\mathrm{Co}, \mathrm{Fe}$, $\mathrm{Mn}$ and $\mathrm{Zn}$; the second, for $\mathrm{Al}, \mathrm{Ca}$ and $\mathrm{P}$; the third, for high $\mathrm{Cr}$ and $\mathrm{Cu}$ to high $\mathrm{Co}, \mathrm{Mg}$ and $\mathrm{Ni}$; the fourth, for high Co to high $\mathrm{Mg}$; and the fifth for $\mathrm{K}$ (Table 1).

There was a significant effect of the first and third soil PC axes on species stoichiometric distinctiveness $(P<0.001$, Fig. 2, Table S1). These axes, as detailed above, were responsible for a gradient in metals rather than macronutrients, which is indicative of a general positive relationship between soil metal concentration and stoichiometric distinctiveness. We also found a weak significant effect of the second PC axis which represents a gradient of $\mathrm{Al}$ and the macronutrients $\mathrm{Ca}$ and $\mathrm{P}(P<0.05$, Fig. 2; Table 1$)$.

Species with high distinctiveness tended to have either high $\mathrm{Al}, \mathrm{Co}, \mathrm{Cr}$ or Ni (Fig. 3a). For instance, amongst the species with highest distinctiveness (Fig. 3a), there were three species of Symplocos (Symplocaceae) with high Al (23,800-36,600 mg kg${ }^{1}$ ) and $\mathrm{Cr}$ (18.8-97.2 $\left.\mathrm{mg} \mathrm{kg}^{-1}\right)$, Cr was also high in one morphospecies (a term used for a species collected that does not match previously described species) of both Syzygium (Myrtaceae) (55.6 $\mathrm{mg} \mathrm{kg}^{-1}$ ) and Chionanthus (Oleaceae) (89.4 $\mathrm{mg} \mathrm{kg}^{-1}$ ). High Co and Ni was found in a morphospecies of Ostodes (Euphorbiaceae) (165 mg kg ${ }^{-1} \mathrm{Co}$ and $202 \mathrm{mg} \mathrm{kg}^{-1} \mathrm{Ni}$ ) and Sauropus (Phyllanthaceae) (114 $\mathrm{mg} \mathrm{kg}^{-1} \mathrm{Co}$ and $484 \mathrm{mg} \mathrm{kg}^{-1}$ $\mathrm{Ni})$. High $\mathrm{Ni}$ was found in Sarcotheca celebica (Oxalidaceae) (1080 mg kg-1). There were also two species with high distinctiveness due to elevated $\mathrm{Ca}$ concentrations, Dendrocnide microstigma (Urticaceae) $\left(58,800 \mathrm{mg} \mathrm{kg}^{-1}\right)$ and Drypetes ovalis (Putranjivaceae) $\left(65,400 \mathrm{mg} \mathrm{kg}^{-1}\right)$ (Fig. 3a).

\section{Discussion}

We found that tropical tree leaf stoichiometry shows limited change in the face of soil heterogeneity - except for some species found on ultramafic soils that are distinct from all others. This warrants two points for discussion: (1) why do we find limited effects of soil on leaf stoichiometry in our study system? And (2) why do ultramafic soils increase stoichiometric distinctiveness of tropical trees?

Previously, log-linear relationships between soil and tissue stoichiometry, specifically N:P ratios, have been identified (Elser et al. 2010). In contrast, we found little correlation for many elements between soil and tissue stoichiometry. The likeliest explanation is that, when looking at a broad spectrum of elements across soils, most species' leaf stoichiometry remains similar, buffered from variation in soil stoichiometry. This is because stoichiometry within the upper and lower bounds of a range of concentrations is needed to support cellular processes, irrespective of soil type (Meunier et al. 2014; González et al. 2017). However, some of the elements that do not obey this rule are worth noting. We see strong positive effects of soil $\mathrm{Al}, \mathrm{Ca}$ and $\mathrm{P}$ upon leaf $\mathrm{Ca}$ and $\mathrm{P}$. Positive correlations between these elements in tropical forests has been seen before, both when looking at just tissue stoichiometry (Masunaga et al. 1998; Metali et al. 2015) and also, as in our study, between tissue and soil (Asner et al. 2014). Added to that, we find evidence for metal impact as soil $\mathrm{Cr}$ has a strong negative relationship with leaf $\mathrm{P}$, possibly a result of competition between $\mathrm{Cr}$ and phosphate for shared cross-membrane transport proteins (Sinha et al. 2018). This could lead to a potentially influential deficiency in $\mathrm{P}$, considering ultramafic soils are naturally low in $\mathrm{P}$ (Porder and Ramachandran 2013). Broadly, we found minimal effects of most soil element concentrations upon tissue element concentrations. When we did find effects, they are not necessarily intuitive i.e. soil element $\mathrm{X}$ does not directly influence leaf element $\mathrm{X}$. Macronutrients tended to have a positive relationship between soils and leaves whereas other metals did not. When soil metals ( $\mathrm{Cr}$ and $\mathrm{Fe}$ ) did covary with leaf elements it was not in the reciprocal elements but others (P and Ni). It appears that the complex relationship between elements required for plant function (Kaspari and Powers 2016) is reflected by an equally multi-faceted relationship between soils and plant tissues.

Why, in ultramafic communities, have we found some species with high stoichiometric distinctiveness (Fig. 3b)? It has been suggested that plants are generally adapted for competition, stress tolerance or rapid establishment after recent disturbance (Grime 1977). Previously, species adapted for competition or rapid establishment have been shown to have reduced 
(a)

Leaf stoichiometry

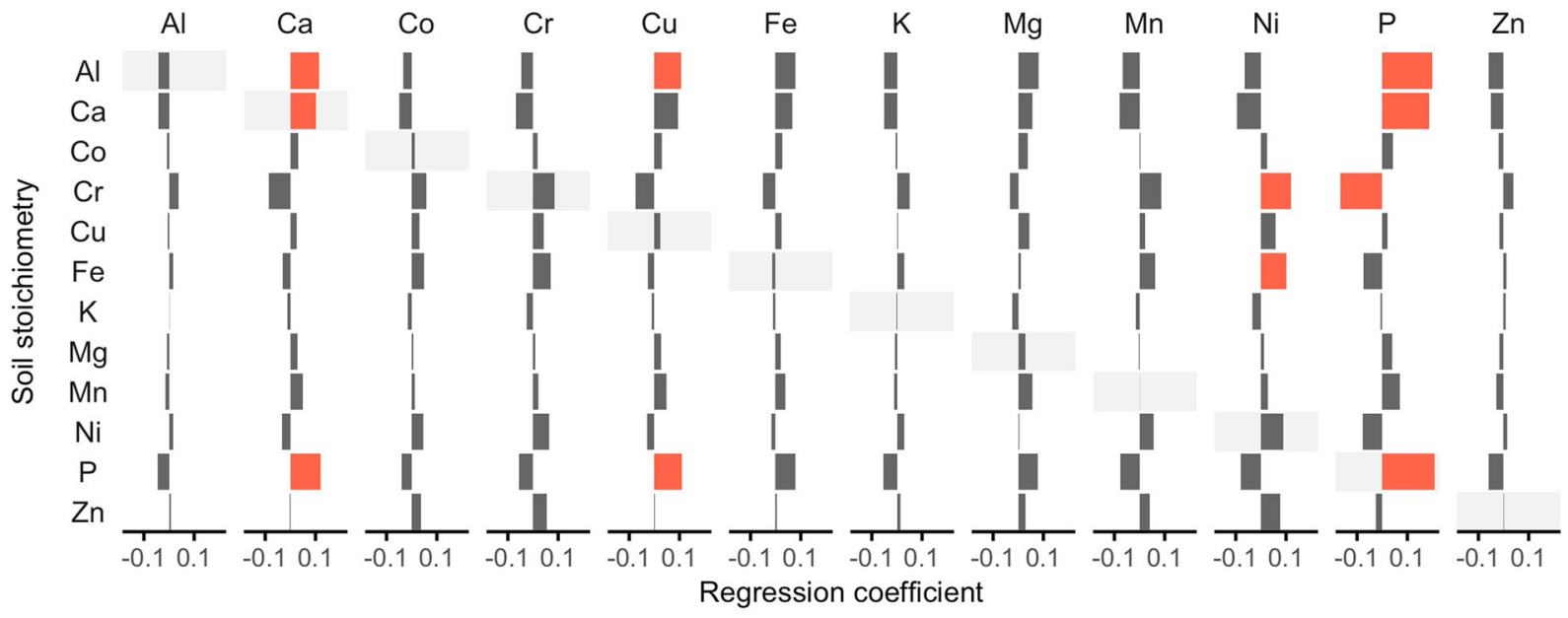

(b)
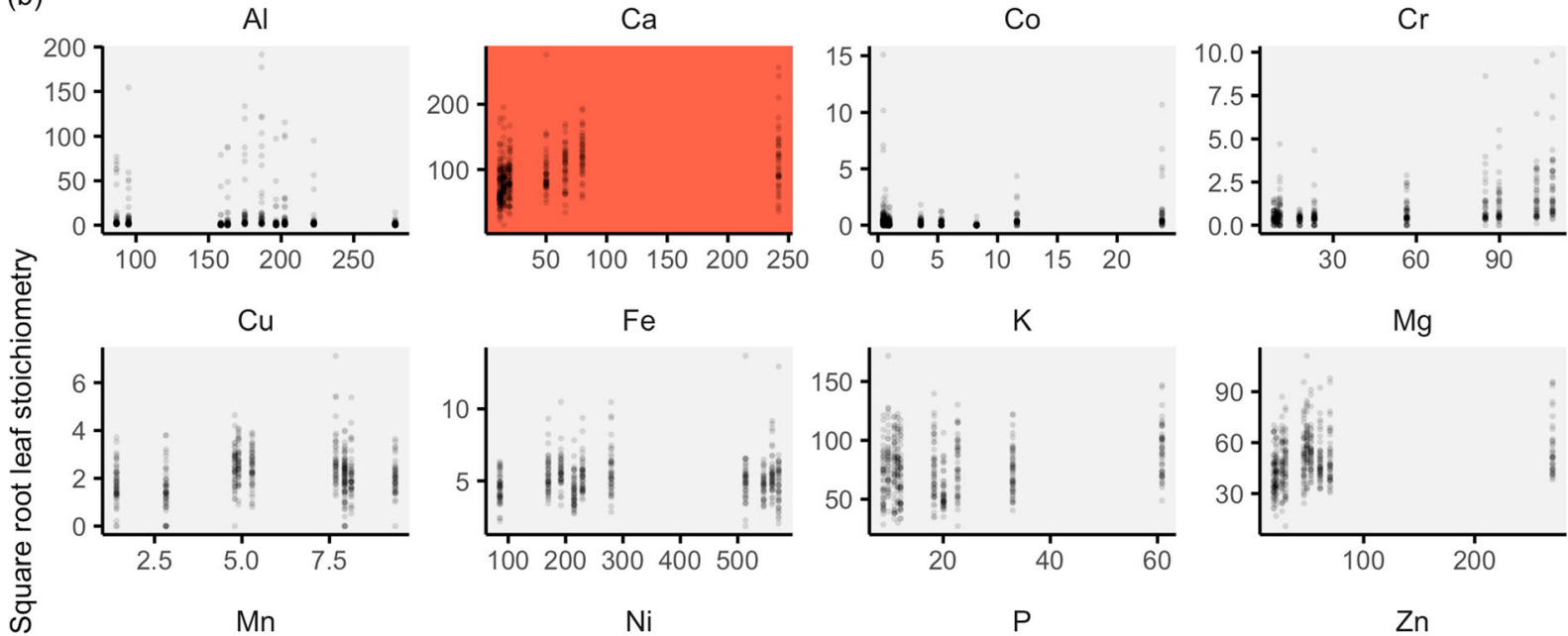

$\mathrm{Fe}$

$\mathrm{K}$
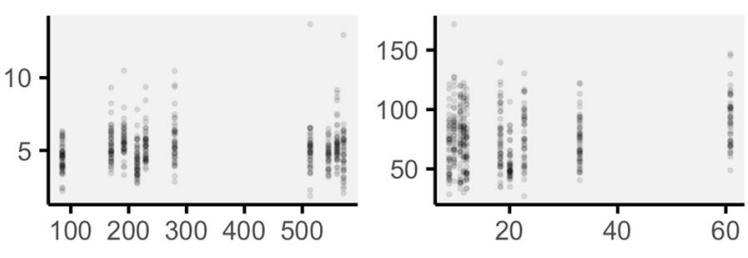

$\mathrm{Mg}$

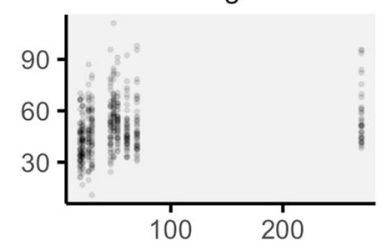

$\mathrm{Ni}$
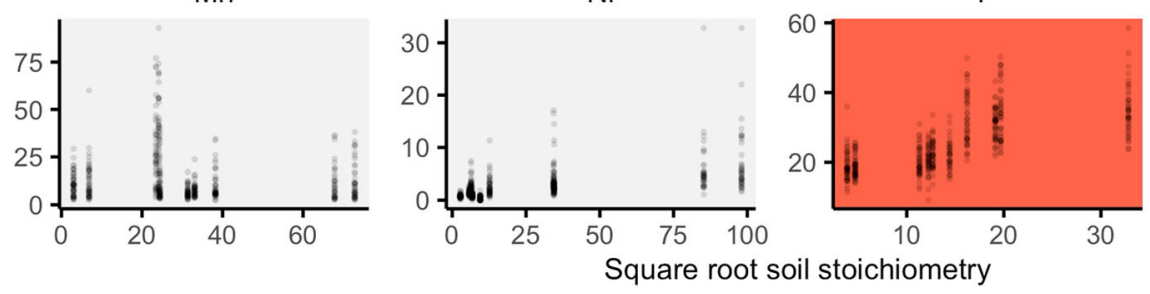

$\mathrm{Zn}$

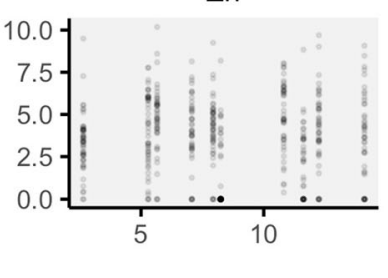

Fig. 1 a Regression coefficients from partial least squares (PLS) regression of the relationships between soil and leaf element concentrations in tree communities of Sulawesi, Indonesia. Large effects of soil metal upon leaf metal (coefficient $>0.1$ or $<-0.1$ ) are bars coloured red. Effects of soil upon reciprocal leaf element concentration have a light grey background. b Pairwise relationships between soil element and reciprocal leaf element. Large effects $(<-0.1$ or $>0.1)$ from the PLS regression are in red distinctiveness (based upon traits) (Umaña et al. 2017a). Our data suggests that increased distinctiveness could be a result of stress tolerance. We find that species with high stoichiometric distinctiveness have high concentrations of metals not classified as macronutrients (Fig. 3a).
Metal accumulation is largely found in species that tolerate the stresses of metal-rich soils (van der Ent et al. 2013a). Furthermore, metal accumulator species are often outcompeted in more benign environments (Reeves et al. 1999) - another signifier of stress tolerance 
Table 1 Soil principal component (PC) loadings for PC axes used in the analysis of leaf stoichiometry across tree communities in Sulawesi, Indonesia. Percentage of total explained by each PC axis is in brackets

\begin{tabular}{llllll}
\hline Element & PC1 (45\%) & PC2 $(23 \%)$ & $\begin{array}{l}\text { PC3 } \\
(12 \%)\end{array}$ & $\begin{array}{l}\text { PC4 } \\
(8 \%)\end{array}$ & $\begin{array}{r}\text { PC5 } \\
(7 \%)\end{array}$ \\
\hline $\mathrm{P}$ & 0.12 & 0.45 & 0.09 & 0.02 & 0.02 \\
$\mathrm{~K}$ & 0.19 & -0.04 & 0.04 & -0.08 & 0.94 \\
$\mathrm{Ca}$ & 0.14 & 0.44 & 0.03 & 0.00 & -0.17 \\
$\mathrm{Mg}$ & -0.19 & 0.03 & 0.27 & 0.84 & 0.13 \\
$\mathrm{Fe}$ & -0.41 & 0.00 & -0.24 & 0.05 & 0.03 \\
$\mathrm{Al}$ & 0.07 & 0.42 & -0.04 & -0.05 & 0.04 \\
$\mathrm{Mn}$ & -0.35 & 0.07 & 0.43 & 0.02 & 0.06 \\
$\mathrm{Cu}$ & -0.35 & 0.05 & -0.32 & 0.04 & 0.07 \\
$\mathrm{Zn}$ & -0.40 & 0.10 & -0.14 & -0.15 & 0.20 \\
$\mathrm{Ni}$ & -0.34 & 0.01 & 0.40 & -0.08 & -0.07 \\
$\mathrm{Cr}$ & -0.33 & -0.05 & -0.47 & 0.03 & 0.01 \\
$\mathrm{Co}$ & -0.30 & 0.07 & 0.37 & -0.49 & 0.03 \\
\hline
\end{tabular}

(Grime 1977). Therefore, it appears that in diverse tropical forest, increased stoichiometric distinctiveness allows tree species to tolerate metal-rich ultramafic soils.

The observation of species becoming more distinct in response to stress contrasts with evidence gathered from other abiotic gradients. For communities exposed to stressful climatic change with elevation or along a soil fertility gradient the response is the reduction in species distinctiveness (Laughlin et al. 2015; Verboom et al. 2017; Umaña and Swenson 2019), where the environment removes species that are far from their optimum in stressful conditions. However, we show that under edaphic stress, the response from a stoichiometric perspective can be increasing distinctiveness. This is presumably because there are alternate strategies of optimum fitness within the metal-rich stressful environment (Marks and Lechowicz 2006; Worthy et al. 2020). The presence of alternate strategies indicates increasing difference in the biotic and abiotic environment occupied by species (i.e. niche differentiation) (Letten et al. 2017; Peñuelas et al. 2019). This tends to reflect species competing less for key resources - which is often touted for communities in stressful environments (Freestone 2006; Niu et al. 2020).

Stoichiometric distinctiveness may also be linked to niche differentiation. In the sites studied here, it is generally the accumulation of the metals $\mathrm{Al}, \mathrm{Co}, \mathrm{Cr}$ and $\mathrm{Ni}$ in tissue that causes distinctiveness (we also find a few cases of high distinctiveness due to high leaf $\mathrm{Ca}$ on limestone; Fig. 3a). Metal accumulation may offer a defence against herbivory by reducing palatability, in a similar way to polyphenols and proteases (Boyd 2004; Kazemi-Dinan et al. 2014; Volf et al. 2018; Coley et al. 2019). High leaf metal concentrations may also aid conspecific recruitment, because competitors are less able to deal with localised spikes in soil metal concentrations that result from leaf litter with high metal concentrations (Boyd and Martens 1998; Boyd and Jaffré 2001; Mohiley et al. 2020). These interactions should be mediated by intraspecific variability in stoichiometric distinctiveness, particularly considering the facultative nature of metal accumulation between many populations (Pollard et al. 2014). How, and if, the above mechanisms affect competition in tropical forests remains uncertain. If greater stoichiometric distinctiveness does reflect greater niche differentiation we expect it to allow species to persist when they would otherwise be outcompeted and removed from communities (Levine and HilleRisLambers 2009). This should contribute to the coexistence of species in high diversity ultramafic rich tropical regions (Rahbek et al. 2019).
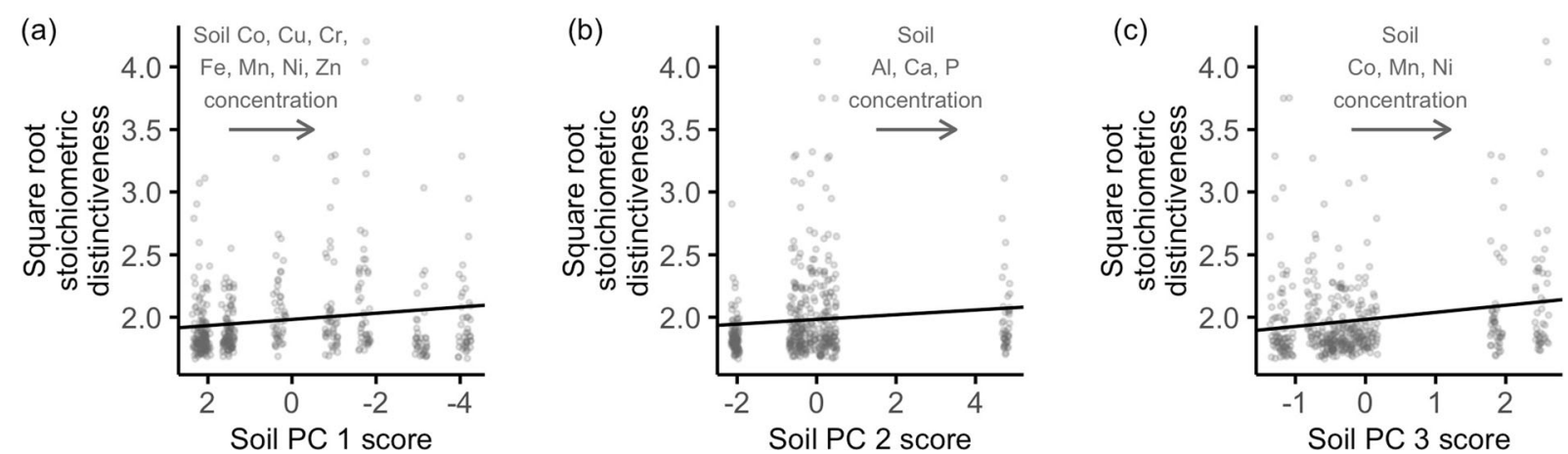

Fig. 2 Significant effect of soil principal components (PC) (a) $1(\mathrm{p}<0.001)$, (b) $2(\mathrm{p}<0.05)$ and $(\mathbf{c}) 3$ (p $<0.001)$ upon species stoichiometric distinctiveness identified with phylogenetic generalised least squares regression for tree communities in Sulawesi, Indonesia 
(a) Ultramafic Non ultramafic

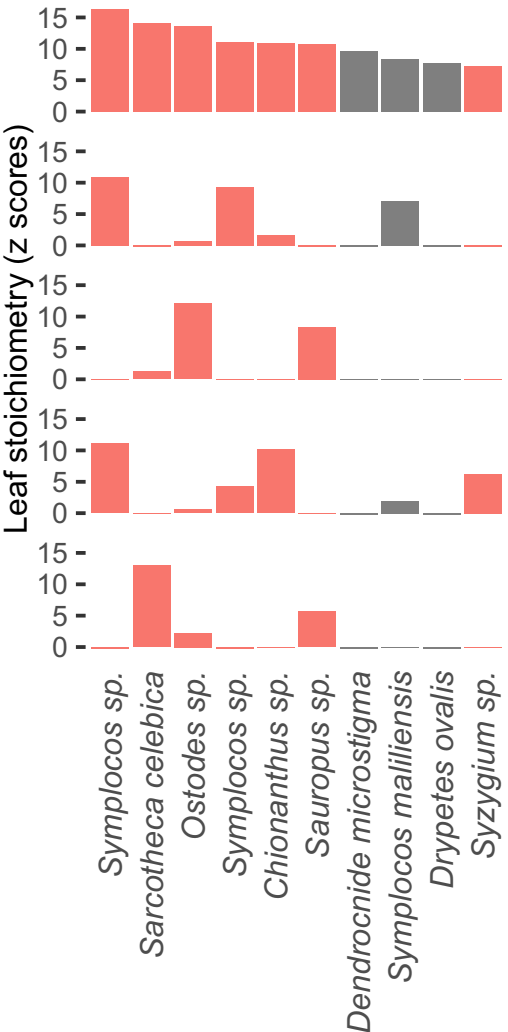

\section{Stoichiometric} distinctiveness

Al

Co

$\mathrm{Cr}$

$\mathrm{Ni}$

(b)

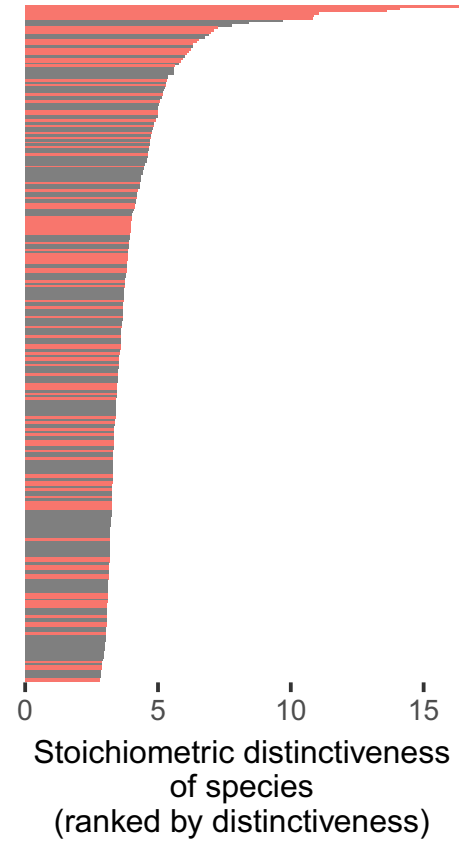

b Stoichiometric distinctiveness values of all species across tree

Fig. 3 a Metal elements ( $\mathrm{Al}, \mathrm{Co}, \mathrm{Cr}, \mathrm{Ni})$ in leaves of the ten species with greatest stoichiometric distinctiveness across contrasing tree communities in Sulawesi, Indonesia.

Our results come with the caveat of not using soil $\mathrm{pH}$ or bioavailable soil element data - the former determining the latter. Although our finding that increasing soil metal drives increasing leaf metal makes sense, in terms of biology, addition of this extra data would reinforce the conclusions presented. Despite this drawback, examination of remote ultramafic tropical forest communities are rare. This study is a starting point for understanding these complex diverse systems that are threatened by increasing human demand for metals and the mining this requires (van der Ent et al. 2013b). We found that the effects of metal-rich ultramafic soils upon tropical trees is not simply a change in leaf stoichiometry across all species. Species mostly retain similar leaf stoichiometry irrespective of substrate. However, some species on ultramafic soils accumulate metals (e.g. Cr, $\mathrm{Ni}$ ), resulting in distinct stoichiometry from all other members of the community. This variable communities in Sulawesi. Red bars indicate the presence of species in ultramafic communities

stoichiometric distinctiveness likely has implications for interspecific competition in highly diverse tropical forests.

Supplementary Information The online version contains supplementary material available at https://doi.org/10.1007/s11104021-04839-7.

Acknowledgements We acknowledge the Indonesian Ministry of Research and Technology (RisTek) for permission to perform fieldwork and Herbarium Bogoriense (BO) for the Memorandum of Understanding and Material Transfer Agreement to support this permission. We thank Indonesian forestry departments and staff at Aliansi Konservasi Tompotika for support in the field. Fieldwork was only possible due to the help of guides: Aga, Yes, Amin, Muksin, Sumardin, Dado, Hanya, Ete, Asrion, Lendo, Manto and Peno. LAT's funding was provided by the Bentham Moxon Trust, Coalbourn Trust, Botanical Research Fund, an MMU postgraduate studentship and Emily Holmes awards. FQB thanks NERC for funding a trip to Sulawesi. We thank David McKendry for help 
with leaf sample analysis and the Indonesian Agricultural Research Agency (Badan Litbang Kementerian Pertanian) for conducting soil analysis. We thank Jennifer Rowntree, Tim Baker, Giacomo Sellan and three anonymous reviewers for comments that much improved the manuscript.

Data availability Upon acceptance data will be made available here: https://figshare.com/authors/Liam_Trethowan/8268603.

Open Access This article is licensed under a Creative Commons Attribution 4.0 International License, which permits use, sharing, adaptation, distribution and reproduction in any medium or format, as long as you give appropriate credit to the original author(s) and the source, provide a link to the Creative Commons licence, and indicate if changes were made. The images or other third party material in this article are included in the article's Creative Commons licence, unless indicated otherwise in a credit line to the material. If material is not included in the article's Creative Commons licence and your intended use is not permitted by statutory regulation or exceeds the permitted use, you will need to obtain permission directly from the copyright holder. To view a copy of this licence, visit http://creativecommons.org/licenses/by/4.0/.

\section{References}

Ågren GI (2008) Stoichiometry and nutrition of plant growth in natural communities. Annu Rev Ecol Evol Syst 39:153-170

Ågren GI, Weih M (2020) Multi-dimensional plant element stoichiometry-looking beyond carbon, nitrogen, and phosphorus. Front Plant Sci 11:23

Andresen E, Peiter E, Küpper H (2018) Trace metal metabolism in plants. J Exp Bot 69:909-954

Asner GP, Martin RE, Tupayachi R et al (2014) Amazonian functional diversity from forest canopy chemical assembly. PNAS 111:201401181

Baker TR, Pennington RT, Dexter KG et al (2017) Maximising synergy among tropical plant systematists, ecologists, and evolutionary biologists. TREE 32:258-267

Boyd RS (2004) Ecology of metal hyperaccumulation. New Phyt 162:563-567

Boyd RS, Jaffré T (2001) Phytoenrichment of soil Ni content by Sebertia acuminata in New Caledonia and the concept of elemental allelopathy. S Afr J Sci 97:535-538

Boyd RS, Martens SN (1998) The significance of metal hyperaccumulation for biotic interactions. Chemoecology 8 : $1-7$

Brearley FQ (2013) Nitrogen stable isotopes indicate differences in nitrogen cycling between two contrasting Jamaican montane forests. Plant Soil 367:465-476

Cleveland CC, Townsend AR, Taylor P et al (2011) Relationships among net primary productivity, nutrients and climate in tropical rain forest: a pan-tropical analysis. Ecol Lett 14: 939-947

Coley PD, Endara M-J, Ghabash G et al (2019) Macroevolutionary patterns in overexpression of tyrosine: an anti-herbivore defence in a speciose tropical tree genus, Inga (Fabaceae). J Ecol 107:1620-1632
D'Andrea R, Guittar J, O’Dwyer JP et al (2020) Counting niches: abundance-by-trait patterns reveal niche partitioning in a Neotropical forest. Ecology 101:e03019

Elser JJ, Fagan WF, Kerkhoff AJ et al (2010) Biological stoichiometry of plant production: metabolism, scaling and ecological response to global change. New Phyt 186:593-608

Freestone AL (2006) Facilitation drives local abundance and regional distribution of a rare plant in a harsh environment. Ecology 87:2728-2735

Galey ML, van der Ent A, Iqbal MCM, Rajakaruna N (2017) Ultramafic geoecology of South and Southeast Asia. Bot Stud 58:18

Gastauer M, Neto M, Alves JA (2017) Updated angiosperm family tree for analyzing phylogenetic diversity and community structure. Acta Bot Brasilica 31:191-198

González AL, Dézerald O, Marquet PA et al (2017) The multidimensional stoichiometric niche. Front Ecol Evol 5:110

Grenié M, Denelle P, Tucker CM et al (2017) funrar: an R package to characterize functional rarity. Divers Distrib 23:13651371

Grime JP (1977) Evidence for the existence of three primary strategies in plants and its relevance to ecological and evolutionary theory. Am Nat 111:1169-1194

Hurlbert SH (1984) Pseudoreplication and the design of ecological field experiments. Ecol Monogr 54:187-211

Ives AR (2018) Mixed and phylogenetic models: a conceptual introduction to correlated data. Retrieved from: https://leanpub.com/correlateddata

Kaspari M, Powers JS (2016) Biogeochemistry and geographical ecology: embracing all twenty-five elements required to build organisms. Am Nat 188:S62-S73

Kazakou E, Dimitrakopoulos PG, Baker AJM et al (2008) Hypotheses, mechanisms and trade-offs of tolerance and adaptation to serpentine soils: from species to ecosystem level. Biol Rev 83:495-508

Kazemi-Dinan A, Thomaschky S, Stein RJ et al (2014) Zinc and cadmium hyperaccumulation act as deterrents towards specialist herbivores and impede the performance of a generalist herbivore. New Phyt 202:628-639

Keenan TF, Niinemets Ü (2016) Global leaf trait estimates biased due to plasticity in the shade. Nat Plants 3:16201

Kerkhoff AJ, Fagan WF, Elser JJ, Enquist BJ (2006) Phylogenetic and growth form variation in the scaling of nitrogen and phosphorus in the seed plants. Am Nat 168:E103-E122

Kraft NJ, Valencia R, Ackerly DD (2008) Functional traits and niche-based tree community assembly in an Amazonian forest. Science 322:580-582

Kraft NJ, Godoy O, Levine JM (2015) Plant functional traits and the multidimensional nature of species coexistence. PNAS 112:797-802

Küpper H, Andresen E (2016) Mechanisms of metal toxicity in plants. Metallomics 8:269-285

Lalnunzira C, Brearley FQ, Tripathi SK (2019) Root growth dynamics during recovery of tropical mountain forest in North-east India. J Mount Sci 16:2335-2347

Lange B, van der Ent A, Baker AJM et al (2017) Copper and cobalt accumulation in plants: a critical assessment of the current state of knowledge. New Phyt 213:537-551

Laughlin DC, Joshi C, Richardson SJ et al (2015) Quantifying multimodal trait distributions improves trait-based 
predictions of species abundances and functional diversity. $\mathrm{J}$ Veg Sci 26:46-57

Letten AD, Ke P-J, Fukami T (2017) Linking modern coexistence theory and contemporary niche theory. Ecol Monogr 87: 161-177

Levin SA, Muller-Landau HC (2000) The emergence of diversity in plant communities. C R Acad Sci III 323:129-139

Levine JM, HilleRisLambers J (2009) The importance of niches for the maintenance of species diversity. Nature 461:254-257

Liu K, Niu Y, Konishi M et al (2017) Discovery of nitrate-CPKNLP signalling in central nutrient-growth networks. Nature 545:311

Lopez S, Benizri E, Erskine PD et al (2019) Biogeochemistry of the flora of Weda Bay, Halmahera Island (Indonesia) focusing on nickel hyperaccumulation. J Geochem Explor 202: 113-127

MacArthur R, Levins R (1967) The limiting similarity, convergence, and divergence of coexisting species. Am Nat 101: 377-385

Magallón S, Gómez-Acevedo S, Sánchez-Reyes LL, HernándezHernández T (2015) A metacalibrated time-tree documents the early rise of flowering plant phylogenetic diversity. New Phyt 207:437-453

Marks CO, Lechowicz MJ (2006) Alternative designs and the evolution of functional diversity. Am Nat 167:55-66

Masunaga T, Kubota D, Hotta M, Wakatsuki T (1998) Mineral composition of leaves and bark in aluminum accumulators in a tropical rain forest in Indonesia. J Soil Sci Plant Nutr 44: 347-358

Metali F, Salim KA, Burslem DFRP (2012) Evidence of foliar aluminium accumulation in local, regional and global datasets of wild plants. New Phyt 193:637-649

Metali F, Salim KA, Tennakoon K, Burslem DFRP (2015) Controls on foliar nutrient and aluminium concentrations in a tropical tree flora: phylogeny, soil chemistry and interactions among elements. New Phyt 205:280-292

Meunier CL, Malzahn AM, Boersma M (2014) A new approach to homeostatic regulation: towards a unified view of physiological and ecological concepts. PLoS One 9:e107737

Meunier CL, Boersma M, El-Sabaawi R et al (2017) From elements to function: toward unifying ecological stoichiometry and trait-based ecology. Front Environ Sci 5:18

Mohiley A, Tielbörger K, Seifan M, Gruntman M (2020) The role of biotic interactions in determining metal hyperaccumulation in plants. Funct Ecol 34:658-668

Moores E (2011) Serpentinites and other ultramafic rocks. In: Serpentine: The evolution and ecology of a model system. University of California Press, Berkeley, pp 3-28

Niu K, Zhang S, Lechowicz MJ (2020) Harsh environmental regimes increase the functional significance of intraspecific variation in plant communities. Funct Ecol 34:1666-1677

Ooms J, Chamberlain S, Webb CO et al (2018) phylocomr: Interface to 'Phylocom'. R package version 010. Retrieved from https://CRAN.R-project.org/package=phylocomr

Parker GA, Maynard Smith J (1990) Optimality theory in evolutionary biology. Nature 348:27

Peng J-S, Guan Y-H, Lin X-J et al (2020) Comparative understanding of metal hyperaccumulation in plants: a mini-review. Environ Geochem Health: https://doi.org/10.1007 /s10653-020-00533-2
Peñuelas J, Fernández-Martínez M, Ciais P et al (2019) The bioelements, the elementome, and the biogeochemical niche. Ecology 100:e02652

Pinheiro J, Bates D, DebRoy S et al (2017) nlme: Linear and nonlinear mixed effects models. R package version 3.1: Retrieved from https:/CRAN.R-project.org/package=nlme

Pollard AJ, Reeves RD, Baker AJ (2014) Facultative hyperaccumulation of heavy metals and metalloids. Plant Sci 217:8-17

Porder S, Ramachandran S (2013) The phosphorus concentration of common rocks - a potential driver of ecosystem $P$ status. Plant Soil 367:41-55

R Core Team (2019) R: A language and environment for statistical computing. R Foundation for Statistical Computing, Vienna

Rahbek C, Borregaard MK, Antonelli A et al (2019) Building mountain biodiversity: geological and evolutionary processes. Science 365:1114-1119

Reeves RD, Baker AJM, Borhidi A, Berazain R (1999) Nickel hyperaccumulation in the serpentine flora of Cuba. Ann Bot 83:29-38

Roumet C, Birouste M, Picon-Cochard C et al (2016) Root structure-function relationships in 74 species: evidence of a root economics spectrum related to carbon economy. New Phyt 210:815-826

Sardans J, Peñuelas J (2013) Tree growth changes with climate and forest type are associated with relative allocation of nutrients, especially phosphorus, to leaves and wood. Global Ecol Biogeogr 22:494-507

Sinha V, Pakshirajan K, Chaturvedi R (2018) Chromium tolerance, bioaccumulation and localization in plants: an overview. J Environ Manage 206:715-730

Stark J, Lehman R, Crawford L et al (2017) Does environmental heterogeneity drive functional trait variation? A test in montane and alpine meadows. Oikos 126:1650-1659

Thompson K, Parkinson JA, Band SR, Spencer RE (1997) A comparative study of leaf nutrient concentrations in a regional herbaceous flora. New Phyt 136:679-689

Trethowan LA, Eiserhardt WL, Girmansyah D et al (2020) Floristics of forests across low nutrient soils in Sulawesi, Indonesia. Biotropica 52:1309-1318

Tripler CE, Kaushal SS, Likens GE, Todd Walter M (2006) Patterns in potassium dynamics in forest ecosystems. Ecol Lett 9:451-466

Tuah SJ, Jamal YM, Limin SH (2003) Nutritional characteristics in leaves of plants native to tropical peat swamps and heath forests of Central Kalimantan, Indonesia. Tropics 12:221245

Turner BL, Brenes-Arguedas T, Condit R (2018) Pervasive phosphorus limitation of tree species but not communities in tropical forests. Nature 555:367-370

Umaña MN, Swenson NG (2019) Intraspecific variation in traits and tree growth along an elevational gradient in a subtropical forest. Oecologia 191:153-164

Umaña MN, Mi X, Cao M et al (2017a) The role of functional uniqueness and spatial aggregation in explaining rarity in trees. Global Ecol Biogeogr 26:777-786

Umaña MN, Zhang C, Cao M et al (2017b) A core-transient framework for trait-based community ecology: an example from a tropical tree seedling community. Ecol Lett 20:619628 
Utteridge TMA, Bramley G (2015) Tropical plant families identification handbook, 2nd edn. Royal Botanic Gardens, Kew, Richmond

van der Ent A, Baker AJM, Reeves RD et al (2013a) Hyperaccumulators of metal and metalloid trace elements: facts and fiction. Plant Soil 362:319-334

van der Ent A, Baker AJM, van Balgooy MMJ, Tjoa A (2013b) Ultramafic nickel laterites in Indonesia (Sulawesi, Halmahera): mining, nickel hyperaccumulators and opportunities for phytomining. J Geochem Explor 128:72-79

van der Ent A, Mak R, de Jonge MD, Harris HH (2018a) Simultaneous hyperaccumulation of nickel and cobalt in the tree Glochidion cf. sericeum (Phyllanthaceae): elemental distribution and chemical speciation. Sci Rep 8:9683

van der Ent A, Mulligan DR, Repin R, Erskine PD (2018b) Foliar elemental profiles in the ultramafic flora of Kinabalu Park (Sabah, Malaysia). Ecol Res 33:659-674

Verboom GA, Stock WD, Cramer MD (2017) Specialization to extremely low-nutrient soils limits the nutritional adaptability of plant lineages. Am Nat 189:684-699

Violle C, Thuiller W, Mouquet N et al (2017) Functional rarity: the ecology of outliers. Tree 32:356-367
Volf M, Segar ST, Miller SE et al (2018) Community structure of insect herbivores is driven by conservatism, escalation and divergence of defensive traits in Ficus. Ecol Lett 21:83-92

Webb CO, Donoghue MJ (2005) Phylomatic: tree assembly for applied phylogenetics. Mol Ecol Notes 5:181-183

Wehrens R, Mevik B-H (2007) The pls package: principal component and partial least squares regression in R. J Stat Softw 18:2

Worthy SJ, Laughlin DC, Zambrano J et al (2020) Alternative designs and tropical tree seedling growth performance landscapes. Ecology 101:e03007

Wright IJ, Reich PB, Westoby M et al (2004) The worldwide leaf economics spectrum. Nature 428:821-827

Yuan ZY, Chen HY, Reich PB (2011) Global-scale latitudinal patterns of plant fine-root nitrogen and phosphorus. Nat Commun 2:344

Zemunik G, Davies SJ, Turner BL (2018) Soil drivers of localscale tree growth in a lowland tropical forest. Ecology 99 : 2844-2852

Publisher's note Springer Nature remains neutral with regard to jurisdictional claims in published maps and institutional affiliations. 